\title{
Comparing the Strength Behavior of Agro-Industrial Roofing Tile with Ordinary Clay Roofing Tile
}

\author{
Rajalakshmi R S ${ }^{1}$, Aryamol E P2 ${ }^{2}$ Jeenamol Francis ${ }^{3}$, Manjusha M Das ${ }^{4}$, Haritha $\mathrm{M}^{5}$ \\ 1,2,3,4 UG Scholar, Department of Civil Engineering, Gurudeva Institute of Science and Technology, Kerala, India \\ ${ }^{5}$ Assistant Professor, Department of Civil Engineering, Gurudeva Institute of Science and Technology, Kerala, India
}

\begin{abstract}
The use of natural aggregates is increasing day by day due to the new innovations and development taking place in the construction field. Because of these reasons the reuse of demolished constructional waste came into existence so that the solid waste can be minimized thereby reducing the scarcity of natural aggregates. Currently, about 33 million tonnes of copper slag is being generated yearly worldwide. Among that about 6 to 6.5 million tonnes is being contributed by Construction works. Copper slag, an abrasive blasting grit made of granulated slag is gaining importance these days. This work makes use of using copper slag as a replacement for the fine aggregate, M-sand. Rice Husk Ash which is one of the main waste product from agricultural field is also used here along with copper slag. The work also checks on the suitability of using Rice Husk Ash in construction field. The use of these wastes from agricultural and industrial field helps to reduce manufacturing costs as well as the selling price which makes it affordable. Moreover, the problem of disposal of the waste can also be minimized to a certain extend. The work also focuses in analyzing and comparing the strength of the manufactured tile with that of ordinary tile. For this four different mixes were prepared by adding copper slag in proportions of $25 \%, 20 \%, 15 \%$ and $10 \%$ and rice husk ash in proportions of $5 \%, 10 \%, 15 \%, 20 \%$ respectively, keeping an equal percentage of $40 \%$ clay and $30 \%$ red soil in almost all mixes. Experimental investigation like Compressive strength test, Flexural strength test, Water absorption test were carried out for all the prepared mixes. Variations in the experimental results for these different mixes were studied and thus the most suitable and effective mix out of these which can be used for making roofing tile was identified.
\end{abstract}

Keywords-Copper slag, Rice Husk Ash, Compressive strength, Flexural strength, Water absorption

\section{INTRODUCTION}

\section{A. GENERAL}

Nowadays construction technology is rapidly changing by adopting new technologies and innovative methods. New innovations can solve many problems in day to day life. Everyone needs better and affordable life to live in. And for this they make houses with comfortable and best appearances. So to satisfy this every scientist and engineer are working hard to develop and optimize new building materials that would be durable as well as cost effective.

The structure which forms the upper covering of a building is called a roof. And it is the covering which gives protection against wind, snow, rain, sunlight, and other natural calamities. The roof coverings are commonly supported by walls or columns, and it is one of the main parts which gives the aesthetic beauty to a building. The different types of roof materials are AC Sheet, GI Sheet, straw, concrete, metal roofing, roof tiles, etc. The main aim of this project is to overcome these problems by making low cost roofing tiles using agricultural and industrial waste.

\section{B. OBJECTIVES OF STUDY}

1. To study about various scopes of using Rice Husk Ash in the casting of roofing tile.

2. To reduce the hazardous impact of copper slag in environment as a replacement of fine aggregate.

3. To study about various properties and analyze the various strength parameters of roofing tile.

4. Comparison of various properties like strength, water absorption of casted roofing tile with normal roofing tile and thereby evaluating the strength of agro-industrial roofing tile.

\section{MATERIALS}

\section{A. Copper slag}

Copper slag is a by-product obtained during smelting and refining operations of copper ore. These particles are angular, glassy and black in color. Copper slag is an ecological and non-toxic product, shown in Fig.1.During smelting process the generated impurities becomes slag. Normally, about 2.2 tonnes of slag is generated for every tonne of metal production. The generated slag is disposed of as waste. The chemical analysis of copper slag shows that copper content is limited to 0.5 to $2 \%$ and consist of iron, silica, alumina, and calcium oxide.

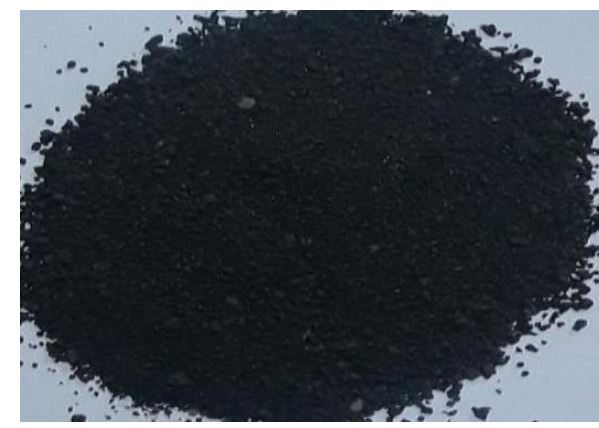

Fig.1. Copper slag

\section{B. Rice Husk Ash}

During the milling process, huge amount of Rice Husk is generated which is the protective covering of rice grains.

Rice husk is an abundantly available waste material in rice mills. The partially burnt husk from milling plants can be used as 
fuel in the boilers for processing of paddy. It is also used as a fuel for power generation. The non-crystalline silicon dioxide is the main constituent of Rice Husk Ash, it posseses a high specific surface area. Main property of silicon dioxide is its high pozzolonic reactivity, as it contains about $90 \%$ silica. Red color is imparted to the soil when it occurs as hematite or as hydro ferric oxide and yellow color is imparted when it occur at hydrate form as limonite. Generally surface soil is red color and the horizon below the soil gets yellowish in color. The Rice Husk Ash is shown in Fig.2.

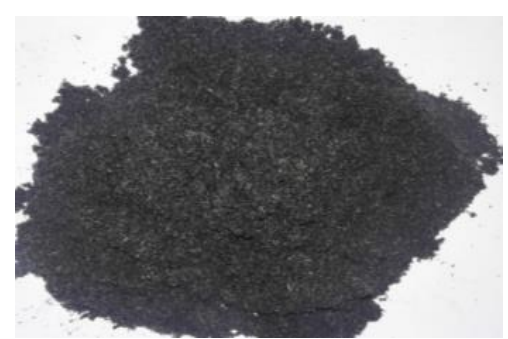

Fig. 2. Rice Husk Ash

\section{Clay}

Clay has the smallest particle size, it contains very little organic matter. It is produced by mixing clay minerals with traces of quartz, metal oxides and organic matter. Clay can appear in different colors such as brown to orange red or white to gray. Clay minerals are formed by the weathering action that occur on primary rock forming mineral so that clay minerals are called secondary silicates. It is very abundant at the earth's surface; they form rocks referred to as shale and are a major component. Commonly clay minerals are phyllosilicates or layer silicates. It is easily compacted with minimal force.

\section{Red soil}

Red soil is the type of soil derived from crystalline rock. This soil has good drainage capacity, they are porous and finely grained. Red soil has got good fertility and thereby improves the plant growth. Red soil is acidic in nature and contain higher iron, aluminum and lime content.

\section{E. Water}

Potable tap water can be used for the mixing of the materials. The water reacts with the materials and bond the components together, thus forming a solid material.

\section{METHODOLOGY}

\section{A. Preliminary test for materials}

a) Specific gravity of materials

Aim: To determine the specific gravity of different materials used for the casting of roofing tile.

Apparatus used: Pycnometer, Balance of kg capacity, glass rod, water bottle.

Theory: Specific gravity of a material is the ratio of its unit weight to that of water. The specific gravity determination is important for the purpose of mix design .i.e., specific gravity of saturated and surface-dry basis is used. Also, specific gravity is an important factor affecting the density of roofing tiles.

\section{Specific gravity $\left(G_{s}\right)=\quad(\underline{W 2-W 1})$ \\ (W4-W1)-(W3-W2)}

Where,

W1 $=$ Weight of Pycnometer

$\mathrm{W}_{2}=$ Weight of pycnometer + Material

W3 = Weight of Pycnometer + Material + Water W4=

Weight of Pycnometer + Water

Note: All weights are taken in grams.

Procedure:

Step 1: Dry the Pycnometer shown in Fig.3 thoroughly and weigh with its cap screwed on (W1).

Step 2: Unscrew the cap and place $600 \mathrm{gm}$ of material in the pycnometer and weight of pycnometer with material is taken $\left(\mathrm{W}_{2}\right)$.

Step 3: Fill the pycnometer with distilled water and mix it thoroughly with glass rod and wipe off the outside portion of pycnometer. Weight of pycnometer, material and water are taken (W3).

Step 4: Empty the pycnometer and fill it with distilled water and weigh (W4).

The results of the above experiment obtained is shown using Table I.

TABLE I. SPECIFIC GRAVITY OF MATERIALS

\begin{tabular}{|c|c|c|c|}
\hline SL.NO & MATERIAL & $\begin{array}{c}\text { NORMAL } \\
\text { RANGE }\end{array}$ & $\begin{array}{c}\text { SPECIFIC } \\
\text { GRAVITY }\end{array}$ \\
\hline 1 & COPPER SLAG & $3.1-4.2$ & 3.90 \\
\hline 2 & RICE HUSK ASH & $2.0-3.0$ & 2.13 \\
\hline 3 & CLAY & $1.8-2.5$ & 2.42 \\
\hline 4 & RED SOIL & $1.2-1.5$ & 1.34 \\
\hline
\end{tabular}

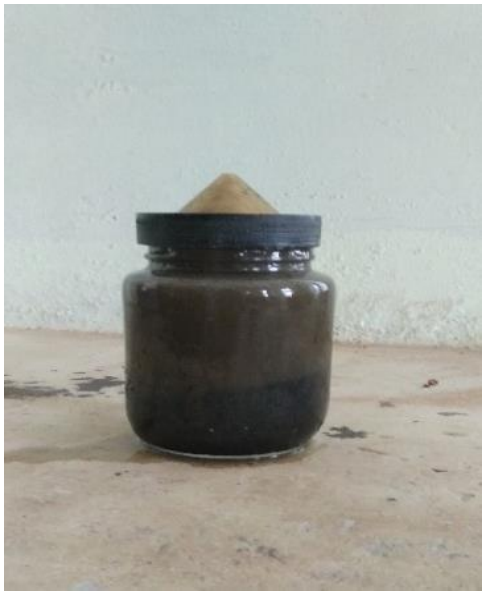

Fig.3. Pycnometer

\section{B. MIX DESIGN}

The process of selecting suitable ingredients and determining their relative proportion is called mix design. The main objective of mix design is producing roofing tile with minimum strength and durability as economically as possible. 


\section{MIX RATIO}

Four different mixes were prepared for this work. Three specimens are casted for each mix ratios and the final result was calculated by taking the average of these. Mix ratios that were used for casting of roofing tile is depicted in Table II.

TABLE II. MIX RATIO

\begin{tabular}{|c|c|c|c|}
\hline MIX & MATERIALS & PERCENTAGE & WEIGHT \\
\hline \multirow{4}{*}{1} & Rice Husk Ash & $5 \%$ & 0.125 \\
\hline & Copper slag & $25 \%$ & 0.625 \\
\hline & Clay & $40 \%$ & 1.000 \\
\hline & Red soil & $30 \%$ & 0.750 \\
\hline \multirow{4}{*}{2} & Rice Husk Ash & $10 \%$ & 0.250 \\
\hline & Copper slag & $20 \%$ & 0.500 \\
\hline & Clay & $40 \%$ & 1.000 \\
\hline & Red soil & $30 \%$ & 0.750 \\
\hline \multirow{4}{*}{3} & Rice Husk Ash & $15 \%$ & 0.375 \\
\hline & Copper slag & $15 \%$ & 0.375 \\
\hline & Clay & $40 \%$ & 1.000 \\
\hline & Red soil & $30 \%$ & 0.750 \\
\hline \multirow{4}{*}{4} & Rice Husk Ash & $20 \%$ & 0.500 \\
\hline & Copper slag & $10 \%$ & 0.250 \\
\hline & Clay & $40 \%$ & 1.000 \\
\hline & Red soil & $30 \%$ & 0.750 \\
\hline
\end{tabular}

\section{MIXING}

First, the materials were weighed according to the batch required. Then the mixture was prepared by hand mixing on a leveled surface keeping it on a water tight platform. On the water tight platform Rice Husk Ash, Copper slag, Clay and red soil are mixed thoroughly until a uniform color was obtained. The water is added to this dry mix carefully ensuring that no water is lost during mixing process until a semi-plastic state was obtained. The mould was cleaned and oiled thereafter and was filled with mix in three layers and compacted. The size of the mould used was $410 \times 235 \mathrm{~mm}$. The same procedure was repeated for the preparation of mixes of different ratios.

\section{E. CASTING AND BURNING}

The specimens were allowed to machine pressing, and then allowed to dry at room temperature. Fig.4 shows the casted roofing tile before burning. After the water from specimen gets evaporated the specimens were allowed to burn at a high temperature. Then the specimens were taken for testing.

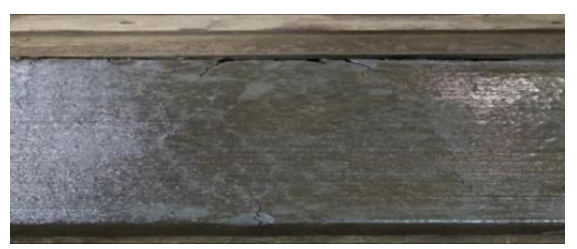

Fig. 4. Casted Tile before burning

\section{TESTING OF SPECIMEN}

The re-moulded specimens after being dried in sunlight and burned for sufficient time period is taken out and tested under standard testing apparatus. The tests that were performed for roofing tiles include the following:
1. Water absorption test
2. Flexural strength test
3. Compressive strength test

\section{A. WATER ABSORPTION TEST}

- AIM: To determine the percentage of water absorption of roofing tiles.

- APPARATUS REQUIRED: A Sensitive balance

- PROCEDURE:

$>$ Dry the roof tiles in an oven at a temperature of $105^{\circ}-110^{0}$ and then cooled and weighed (M1).

$>$ After weighing the specimens is immersed completely in clean water at room temperature for 24 hours.

$>$ Remove each specimen, wipe off the water surface with a damp cloth and weigh the specimen (M2) within 3 minutes after removing the specimen from the tank.

$>$ Then the percentage of water absorption can be calculated from the equation:

\section{Percentage water absorption, $W=\frac{M 2-M 1}{M 1} X 100$}

Where,

M1= Weight of dry specimen

M2 = Weight of specimen immersed in water

The results of percentage water absorption obtained for all the four mixes is been shown in Table III

TABLE III. WATER ABSORPTION TEST

\begin{tabular}{|c|c|c|c|}
\hline MIXES & $\begin{array}{c}\text { DRY } \\
\text { WEIGHT } \\
\text { (M1) }\end{array}$ & $\begin{array}{c}\text { WET } \\
\text { WEIGHT } \\
\text { (M2) }\end{array}$ & $\begin{array}{c}\text { WATER } \\
\text { ABSORPTION } \\
(\boldsymbol{\%})\end{array}$ \\
\hline MIX 1 & 1128 & 1348 & 19.5 \\
\hline MIX 2 & 954 & 1204 & 26.2 \\
\hline MIX 3 & 928.3 & 1239.5 & 33.5 \\
\hline MIX 4 & 843.5 & 1143.8 & 35.6 \\
\hline
\end{tabular}

\section{B. COMPRESSIVE STRENGTH TEST}

- AIM:

To determine the compressive strength of roofing tiles.

- APPARATUS REQUIRED:

Compression testing machine

- PROCEDURE:

$>$ Clean the surface of the machine where specimen is placed. 
$>$ Place the specimen on the flat surface and the load is applied continuously.

$>$ Note the load that break the specimen. That will be the breaking load.

$>$ The compressive strength of the specimen can be calculated by using the equation;

\section{Compressive strength $=\underline{\text { Maximum load }}$} Cross sectional area

The results of compressive strength obtained for all the four mixes is been shown in Table IV

TABLE IV.COMPRESSIVE STRENGTH TEST

\begin{tabular}{|l|l|l|}
\hline MIXES & LOAD & $\begin{array}{l}\text { COMPRESSIVE } \\
\text { STRENGTH(N/mm }\end{array}{ }^{2}$ ) \\
\hline MIX 1 & 791.03 & 8.21 \\
\hline MIX 2 & 521.25 & 5.41 \\
\hline MIX 3 & 370.95 & 3.85 \\
\hline MIX 4 & 94.833 & 1.30 \\
\hline
\end{tabular}

C. FLEXURAL STRENGTH TEST

- AIM:

To determine the flexural strength of roofing tiles

- APPARATUS REQUIRED:

Flexural strength machine

- PROCEDURE:

$>$ The machine used for testing flexural strength is a double lever loading machine. And the load is applied to the specimen

$>$ The load is applied at the rate of 450 to $550 \mathrm{~N} /$ minute as per standard test requirement.

$>$ Note the breaking load of specimen

The results of flexural strength obtained for all the four mixes is been shown in Table $\mathrm{V}$

\section{TABLE V. FLEXURAL STRENGTH TEST}

\begin{tabular}{|l|c|}
\hline MIXES & $\begin{array}{c}\text { BREAKING LOAD PER } \\
\text { MINUTE }\end{array}$ \\
\hline MIX 1 & 605 \\
\hline MIX 2 & 555.0 \\
\hline MIX 3 & 440.0 \\
\hline MIX 4 & 215.0 \\
\hline
\end{tabular}

\section{COMPARISON OF RESULT}

The standard values of clay roofing tiles from IS codes is shown in Table VI. By using these standard values, a comparison was done for the prepared agro-industrial roofing tile in order to find out their strength behavior which includes the compressive strength, flexural strength and also the water absorption rate.

TABLE VI. TEST RESULTS OF STANDARD ROOFING TILE

\begin{tabular}{|c|c|c|}
\hline SL. NO & TESTS & STANDARD VALUE \\
\hline 1 & Water absorption & $18 \%$ \\
\hline 2 & $\begin{array}{c}\text { Compressive } \\
\text { Strength }\end{array}$ & $8 \mathrm{MPa}-10 \mathrm{MPa}$ \\
\hline 3 & Flexural strength & $680-1000 \mathrm{~N} / \mathrm{min}$ \\
\hline
\end{tabular}

\section{A. WATER ABSORPTION}

Table III shows water absorption percentages of the casted specimens at various replacement levels. The percentage of water absorption for standard roofing tiles is about $18 \%$. The water absorption percentage increases with increased percentage of Rice Husk Ash and decreased percentage of copper slag. From the water absorption percentage results, it was found that the best mix for making roof tiles is MIX 1 and the water absorption percentage percentage for the mix was about $19.5 \%$ which is almost close to that of standard roofing tile.

\section{B. COMPRESSIVE STRENGTH}

Table IV shows the average compressive strength in $\mathrm{N} / \mathrm{mm}^{2}$ of the tile specimens at different levels of replacement. The standard range of compressive strength of clay roofing tiles lies between $8 \mathrm{MPa}$ to $10 \mathrm{MPa}$.Compressive strength increases with increased percentage of Rice Husk Ash and decreased percentage of copper slag Therefore, the best mix for making roof tiles is MIX 1 and the compressive strength of MIX 1 roof tile is $8.21 \mathrm{~N} / \mathrm{mm}^{2}$ since it has got almost same value when compared to that of a standard roofing tile.

\section{FLEXURAL STRENGTH}

Table V shows the average flexural strength in $\mathrm{N} / \mathrm{min}$ of the tile specimens at different levels of replacement. In general, the minimum flexural strength required for clay roofing tile is $600 \mathrm{~N} / \mathrm{min}$. According to IS code of clay roofing tile, the range lies between 680 and $1000 \mathrm{~N} / \mathrm{min}$ and the range is different for different sizes of tiles. From this experiment we can see that MIX 1 shows maximum flexural strength at 5\% replacement of Rice Husk Ash and 25\% replacement of copper slag. Therefore, MIX 1 can be used for making roofing tile.

\section{CONCLUSIONS}

From the experimental study, we concluded that the replacement of Rice Husk Ash and Copper Slag for making of roofing tiles will be very effective in the construction industry. In addition to this, it is an effective method for the disposal of Rice Husk Ash and Copper Slag which will reduce the demand for additional waste disposal and decrease the load on existing landfills and incinerators. Copper Slag is the by-product of smelting of copper industry, and it is hazardous in nature. So by using copper slag as a replacement for making roofing tiles, we can reduce the hazardous impact of the same into the environment. By evaluating the results, we arrived in a conclusion that the problems of unavailability and higher cost of clay and red soil in conventional roofing tiles can be reduced by using copper slag and Rice Husk Ash.

From all the tests conducted for roofing tiles, the best and most convenient result was obtained for MIX 1 which uses 5\% replacement of Rice Husk Ash and 25\% replacement of copper slag. The range of water absorption percentage of MIX 1 is almost close to that of conventional roofing tile. And the compressive strength of MIX 1 is higher than that of conventional roofing tiles. The values obtained indicates that it is best suited for making roofing tile very effectively. This is because of the reason that the strength increases when the percentage of RHA decreases and that of copper slag increases. RHA has got cementitious and pozzolonic properties and is porous in nature. RHA is light in weight therefore the density of roofing tile decreases when its concentration increases in mixes. Copper slag has less surface porosity, therefore compressive strength increases due to high bulk density. 
The strength obtained is due the alkali- aggregate reaction taking place in the mixes. Alkaline -aggregate reaction is the reaction between the active mineral constituents of aggregate and the sodium and potassium alkali hydroxide in cement. Here, RHA shows alkaline nature and copper slag shows the properties of fine aggregate. Cementitious RHA reacts with silicious copper slag and hence alkali- silica reaction takes place by forming silica gel. In MIX 1, the alkali- aggregate reaction is less and therefore we obtain more strength than other mixes. This is because of less amount of RHA in MIX 1.We thus came to the conclusion that MIX 1 can be used for making roofing tiles and it has got a higher strength value when compared with a conventional roofing tile. Hence both economical as well as environmental benefits can be achieved using 5\% Rice Husk Ash and 25\% Copper Slag and it can be followed for the making of low cost roofing tiles. Therefore, we can call such a type of roofing tile as Agro- Industrial Roofing Tile.

\section{ACKNOWLEDGMENT}

It is our proud privilege to release the feelings of our gratitude to several persons who helped us directly or indirectly to conduct this project work. First we are thankful to the God Almighty for providing us with everything that we required in completing this project.

We take this opportunity to express our profound gratitude to our guide Ms. Haritha M, M.Tech, Assistant Professor, for her exemplary guidance, monitoring and constant encouragement throughout the course of this work. We are oblique to the Teaching and Non-Teaching staffs, Department of Civil Engineering, for the valuable information provided by them in their respective fields. We are also grateful for their cooperation during the period of our assignment.

Lastly we thank Almighty, Parents, brothers, sisters and valuable friends for their constant encouragement without which our project would not be possible.

\section{REFERENCES}

[1] R.R Chavan and D B Kulkarni, "Performance of copper slag on strength properties as partial replace of fine aggregate in concrete mix design", IJAERS, pp. 95-98, Jul. 2013.

[2] Saravana J, ImthiyasAhamed S - Low Cost Roofing Tiles using Agricultural Wastes, SSRG International Journal of Civil Engineering (SSRG - IJCE) - Volume 4 Issue 3 - March 2017.

[3] Prasanna Kumar, Dr.Shashishankar, Raghavendra, "Utilization of Copper slag in M-Sand as partial replacement of fine aggregate," international journal of latest technology in engineering, Management \& Applied Science, volume VI, Issue XII, December 2017.

[4] Nnamdi O.P, "Low cost materials for Buildings and Construction: A Case study of Rice Husk", Journal of Sustainable Development and Environmental Pollution, 2011.

[5] Opara P.N, "Low cost materials for building and construction," Journal of Sustainable Development and Environmental Protection, 2011, 1,131-211.

[6] IS 3978-1967 Indian Standard Code of Practice for Manufacture of Burnt Clay Mangalore Pattern Roofing Tiles. Yaning Zung, A.E. Ghaly, Bingxi $\mathrm{Li}$, - Physical Proiperties of Corn Residues, American Journal of Biochemistry and Biotechnology, Aug, 2012. ISSN 1553-3468.
[7] Kartini K., Rice Husk Ash - Pozzolanic Material for Sustainability, International Journal of Applied Science and Technology, 2011, 1(6), p. 169-178.

[8] Khalifa S. Al-Jabri, Abdullah H. Al-Saidy, S.K. Al-Oraimi, Makoto Hisada, "Performance of high strength concrete made with copper slag as a fine aggregate" ELSEVIER, pp. 2132-2140, 2009, Vol. 23.

[9] Hwang chao-Lung, Bui Le Anh-Tuan, Chen Chun-Tsun, "Effect of rice husk ash on the strength and durability characteristics of concrete", construction and Building materials, Volume 25, Issue 9, September 2011, 3768-3772.

[10] Harvey Alter, "The composition and environmental hazard of copper slags in the context of basal convention",RCR, vol. 43, pp. 353-360, 2005 .

[11] Wei Wu, Weide Zhang, Guowei Ma. "Mechanical properties of copper slag reinforced concrete under dynamic compression", Construction and building materials, vol. 24, pp. 910-917.

[12] Caijun Shi, Christian Meyer, Ali Behnood, "Utilization of copper slag in cement and concrete", Resources, Conservation and Recycling, vol.52, pp.1115-1120, 2008.

[13] Ayano T, Sakata K, "Durability of concrete with copper slag as the fine aggregate," The 5th CANMET/ACI international conference on durability of concrete, 2000, pp141-158

[14] Agbede Olufemi, Tersoo Akuto, Tiza Michael, Terry Ugama, "Production of concrete roofing tiles using rice husk in partial replacement of cement," international research journal of engineering and technology, volume :03 Issue:06, June 2016, e-ISSN: 2395- 0056, p-ISSN: 2395-0072

[15] Gunasekaran. K et al, -Mechanical and bond properties of coconut shell concretel (2011), construction and building materials $25 \quad 92-98 \mathrm{~K}$. Gunasekaran, P.S. Kumar, Lightweight concrete mix design using coconut shell aggregate, Proceedings of International Conference on Advances in Concrete and Construction, ICACC- 2008 , 7-9 February, 2008, Hyderabad, India pp. 450-459.

[16] Junwei Song, "An experimental of strength properties of concrete admixed with copper slag”, JCPR, vol. 6(4), pp. 250-254, 2014.

[17] Viji C. M, "Shear strength and load settlement behaviour of copper slag in sand pile", IJERT, vol. 3(9), pp. 1090-1094, Sep. 2014.

[18] M. Fadaee, R.Mirhosseini, R. Tabatabaei and M. J. Fadaee, “ Investigation on using copper slag as a part of cementations materials in self compacting concrete", AJCE, vol. 16, pp. 368-381, Dec. 2014

[19] Saravanan J, Sridhar M, -Construction Technology, Challenges and Possibilities of Low Carbon Buildings in Indial, International Journal of Civil Engineering (SSRJ-IJCE), Vol 2 Issue 11, November 2015. ISSN $2348-8352$.

[20] D. Bringha and S. Nagan, "Utilization of Copper Slag as a Partial Replacement of Fine Aggregate in Concrete", IJESE, vol.03, pp. 579 -585, Aug. 2010. 